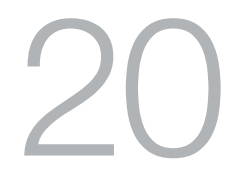

\title{
A Trip from Port Moresby to Suva
}

\section{Bomai D. Witne}

Early in the morning my sister, her husband and Gabriel accompanied me to Jackson's Airport.

'When are you returning?' my sister asked. 'Wednesday, next week,' I replied. 'OK, bring me something from Fiji.'

I smiled and told her I would think about it.

'Do you all have money to pay for your bus home?' I asked them at the airport. They nodded and I asked each of them to reconfirm.

I offered a 10 kina note to my three-year-old nephew and headed for the International Terminal and joined the queue at the check-in counter.

When I fronted the counter, a beautiful woman smiled and asked, 'What's your name?' and put her hands out for my tickets.

'My name is Bomai,' I responded, handing my ticket and passport to her.

'Are you from Simbu?' she asked and I replied, 'How do you know?' 'By looking at your name,' she responded and showed me where to go. 
I compared my experience at Goroka Airport's Air Niugini check-in with my first impression of the female staff at Jackson's as I moved on to the money exchange and the immigration counter.

Soon I was in the departure lounge among the other passengers.

I looked around and saw that there were more passengers of Asian origin then all the other races put together. I did not want to think deeper about this observation and took a book from my bag.

As I was reading, the young man I had met in Goroka smiled and walked over to where I was sitting. We shook hands and began a conversation. He spent most of the time on the mobile phone in his hand, so I returned to my book.

Air Niugini flight PX084, scheduled to fly first to Henderson's Airport in Honiara and then on to Nadi Airport in Fiji, was delayed.

I was used to delays and flight cancellations on domestic Air Niugini flights. I saw some passengers becoming impatient and starting little complaining conversations.

A female staff member of Air Niugini walked over to a woman sitting next to me and said, 'The plane is ready to go but we are waiting for one of the pilots to arrive'.

The woman asked, 'Why?' 'Many Air Niugini pilots walked off the job due to some grievances with management and we are low on pilots', the staffer explained.

What I heard was enough to put my mind at rest and I went back into my conversation with the book.

After a while, a young woman dressed in captain's uniform was escorted by a security officer to the waiting plane. I knew she was the co-captain and got ready for departure.

After going through the ticket check, I boarded the plane and sat in seat 19F. After a few minutes, a beautiful woman walked up the aisle and sat next to me. After a moment of silence, she asked, 'Are you Bomai?' 
'Yes, I am, and your name, please?' She gave a full smile and said, 'I am Lorna, one of the three writers selected to attend the Pacific Writer's Workshop in Fiji. Nice to meet you.'

'Marlene and I were looking out for you in the departure lounge and mistook someone else for you', Lorna added with a smile.

I laughed and asked for Marlene. Lorna pointed to a seat at the front.

Soon Lorna and I were into a conversation about writing, family, education and many things. The conversation kept us busy over rivers, jungles, mountains, lagoons and atolls through clear blue skies across the Solomon Sea.

I tried listening to Bob Marley and Lucky Dube songs and watching movies on the small screen in front of me but could not find any I liked so decided to listen to songs from Landini Aurelio, who sings and promotes his Garifuna culture.

Midway through the journey, a meal of cold potato was served and I requested coffee. After the meal, I looked around the plane and saw many passengers reading the in-flight magazines or had eyes and ears glued to the mini-screen in front of them.

I smiled to myself at what I saw and went for more music. I switched from Landini to the selection of best local sounds from PNG, seeing someone who looked like my colleague at the University of Goroka, Richard Mogu, among the people in the cover.

I heard a few of his songs among the collection. This gave me a sense of why the University of Goroka was lucky to employ such a talented person to teach music and songs to the students.

My mind tried to describe the varying shapes of the clouds. If the plane was crossing over the Arctic I would have seen one or two Inuit at work.

Other clouds reminded me of the ancient Borobudur temple in Indonesia, some of pictures of Disneyland, flocks of sheep, terraces, kaukau (sweet potato) and mountains in the highlands of Papua New Guinea. 
I turned from imagination to songs again. I listened to songs by Eric Clapton and among them was, 'Sky is crying, look at tears down the streets'. I thought the clouds were the way for the sky to form tears and that I was travelling above Clapton's sky.

The music went off as one of the cabin crew announced the plane's preparation for landing at Henderson's at a quarter past two in the afternoon, Solomon Island's time.

Under the clear, blue Solomon sky, I could see a beautiful white coastline below and the roads connecting it to the hinterland. The moving clouds cast shadows on the treetops.

Soon the clouds and forests went out of sight and the plane flew over some human settlements with red soil roads between them, then over several rivers and swamps and then over what appeared to be an extensive oil palm plantation.

It sped over atolls and the bigger islands of the Solomons. An island came into view. It reminded me of Dobu Island in Milne Bay.

A large red ship was floating in the sea with logs on it, which brought to mind the illegal logging in Solomon Islands and other Melanesian countries. The plane descended rapidly and was soon flying over redroofed buildings and coconut palm-roofed houses. We were soon on the runway, at Henderson International Airport.

The passengers for Solomon Islands were asked to disembark while the Nadi-bound passengers were asked to remain in the plane. From where I was sitting, I could see refuelling trucks settling under the wings of the plane. Another aircraft with 'Virgin Australia' insignia landed and many people disembarked.

Lorna and I walked to Marlene's seat and I introduced myself to her. We were soon getting on as if we had known each other for a long time. We took some photos in the aisle.

We were back on our seats when I noticed a leak in the plane's wing close to me, which I reported to one of the cabin crew. Soon the captain was on the ground. When he returned to his seat he announced it was condensation due to change of temperature. My mind was at ease and soon the plane was hitting Henderson's runway. 
The plane was soon in the air over the township of Honiara and heading southeast on its way to Nadi. The cabin crew distributed two forms, one on ebola virus and the other labelled 'Fiji arrival card'.

The information revealed that Fiji had strong immigration laws. After filling in the forms, I sat back and listened to more PNG and Celine Dion music. The map on the screen in front of me indicated the plane was flying over Vanuatu.

The sun began to set, painting the clouds with gold and copper. At some points the sun rays described beautiful rainbow-like lines. After a few minutes, the plane was plunging through murky clouds and I could see the lights on the left wing. The crew reminded us that the plane was preparing for landing.

A crew member thoroughly sprayed the interior of the plane from one end to the other for Fiji quarantine. Lorna asked me, 'Why didn't the crew do the same on arrival at Henderson's?' I said, 'Maybe the Solomon Island's government is not serious about quarantine issues'.

It was dark outside and the plane flew over settlements with scattered lights. More lights came into view and we landed at Nadi International airport. Lorna, Marlene and I sorted immigration requirements and raced for the domestic terminal to catch the $8 \mathrm{pm}$ flight to Nausori airport in Suva.

It was raining in Nadi and the airport staff issued us with umbrellas to walk to the plane and the cabin crew greeted us with 'Bula' and gave us a moist towel and water.

I reached out for the Fiji Sun and read about Fiji Link's management decision to share its profits with employees. I tried to recall the last time Air Niugini announced it would share its profit with employees. No wonder their airport staff do not care to stand in the rain and distribute umbrellas to passengers.

The flight from Nadi to Nausori was less than 30 minutes and we landed at Nausori around $8.30 \mathrm{pm}$. The light-skinned young man I'd met in Goroka walked towards his mother who was waiting with a camera. She hugged him. 
He introduced me to his mother, who shook hands with me and pointed to a man standing beside us and told us that he was Papua New Guinea's high commissioner to Fiji.

He walked over and shook hands with us.

Lorna, Marlene and I could not find our pick-up car and went to the airport police office to enquire. Two police officers greeted us nicely and asked us to come in and call our contact persons in Fiji.

One police officer offered to call the police boss to assist us. With their help, we were in touch with our contact person in Fiji and the driver arrived in less than 10 minutes to pick us up.

We thanked the police officers and left for the Hotel Peninsula in Suva. The porters at the hotel greeted us with a 'Bula' and carried our luggage to our rooms. 
This text is taken from Touring Pacific Cultures, edited by Kalissa Alexeyeff and John Taylor, published 2016 by ANU Press, The Australian National University, Canberra, Australia. 